\title{
EVOLUTIONARY STEPS IN THE REPRODUCTIVE BIOLOGY OF ANNONACEAE ${ }^{1}$
}

\author{
GERHARD GOTTSBERGER ${ }^{2}$
}

\begin{abstract}
Flowers of Annonaceae are characterized by fleshy petals, many stamens with hard connective shields and numerous carpels with sessile stigmas often covered by sticky secretions. The petals of many representatives during anthesis form a closed pollination chamber. Protogynous dichogamy with strong scent emissions especially during the pistillate stage is a character of nearly all species. Scent emissions can be enhanced by thermogenesis. The prevailing reproductive system in the family seems to be self-compatibility. The basal genus Anaxagorea besides exhibiting several ancestral morphological characters has also many characters which reappear in other genera. Strong fruit-like scents consisting of fruit-esters and alcohols mainly attract small fruit-beetles (genus Colopterus, Nitidulidae) as pollinators, as well as several other beetles (Curculionidae, Chrysomelidae) and fruit-flies (Drosophilidae), which themselves gnaw on the thick petals or their larvae are petal or ovule predators. The flowers and the thick petals are thus a floral brood substrate for the visitors and the thick petals of Anaxagorea have to be interpreted as an antipredator structure. Another function of the closed thick petals is the production of heat by accumulated starch, which enhances scent emission and provides a warm shelter for the attracted beetles. Insight into floral characters and floral ecology of Anaxagorea, the sister group of the rest of the Annonaceae, is particularly important for understanding functional evolution and diversification of the family as a whole. As beetle pollination (cantharophily) is plesiomorphic in Anaxagorea and in Annonaceae, characters associated with beetle pollination appear imprinted in members of the whole family. Pollination by beetles (cantharophily) is the predominant mode of the majority of species worldwide. Examples are given of diurnal representatives (e.g., Guatteria, Duguetia, Annona) which function on the basis of fruit-imitating flowers attracting mainly fruit-inhabiting nitidulid beetles, as well as nocturnal species (e.g., large-flowered Annona and Duguetia species), which additionally to most of the diurnal species exhibit strong flower warming and provide very thick petal tissues for the voracious dynastid scarab beetles (Dynastinae, Scarabaeidae). Further examples will show that a few Annonaceae have adapted in their pollination also to thrips, flies, cockroaches and even bees. Although this non-beetle pollinated species have adapted in flower structure and scent compounds to their respective insects, they still retain some of the specialized cantharophilous characters of their ancestors. Index terms: Floral biology, pollination, cantharophily, dichogamy.
\end{abstract}

\section{A EVOLUÇÃO DA BIOLOGIA REPRODUTIVA DE ANNONACEAE}

RESUMO - As flores de Annonaceae são caraterizadas por pétalas carnosas, muitos estames com conectivos duros em forma de escudo e numerosos carpelos com estigmas sésseis que produzem exsudados pegajosos. As pétalas de muitas espécies formam uma câmara de polinização durante a antese. Protoginia e fortes emissões de cheiro, especialmente durante a fase feminina, são características de quase todas as espécies. A maioria das espécies com flores noturnas tem termogênese, o que acelera a emissão de cheiros e fornece um lugar aquecido aos besouros polinizadores. Uma função das pétalas de Anaxagorea e de outras espécies de Annonaceae é a produção de calor através da queima de amido acumulado e da emissão de componentes de cheiro. Apesar de que a maioria de Annonaceae parece ser autocompatível, a dicogamia de certa maneira age contra a autopolinização. A polinização por besouros (a cantarofilia) é o modo predominante na família. $\mathrm{O}$ gênero mais basal da familia parece ser Anaxagorea, cujas flores emitem um cheiro composto de ésteres de frutos e àlcool e atraem principalmente pequenos besouros do gênero Colopterus (Nitidulidae), que normalmente vivem em frutos. Pelo fato de que a polinização por besouros é plesiomórfica em Anaxagorea, características associadas com a cantarofilia aparecem em quase todas as espécies de Annonaceae. Tanto as flores de Anaxagorea como as de outros Annonaceae são predadas por besouros e moscas que comem as pétalas e cujas larvas também se criam nas pétalas ou nos óvulos. Portanto, as pétalas carnosas podem ser interpretadas também como estruturas antipredatoras. São demonstrados casos de polinização por besouros pequenos em flores diurnas (p.e. Guatteria, Duguetia, Annona) e por besouros grandes (Dynastinae, Scarabaeidae) em flores noturnas (p.e. Annona, Duguetia). Algumas Annonaceae são adaptadas a uma polinização por trips (Thysanoptera), moscas, baratas a até abelhas. Apesar de que estes grupos de Annonaceae que não são polinizados por besouros possuem adaptações aos seus insetos específicos, eles ainda mostram algumas características cantarofílicas de seus ancestrais.

Termos de indexação: Biologia floral, polinização, cantarofilia, dicogamia.

Palestra Anonáceas - V Congresso Internacional \& Encontro Brasileiro sobre Annonaceae: do gene à exportação (19 a 23 de Agosto de 2013). Botucatu-SP.

${ }^{2}$ Botanical Garden and Herbarium, University of Ulm, 89081 Ulm, Germany. E-mail: gerhard.gottsberger@uni-ulm.de 


\section{INTRODUCTION}

As an evolutionary old family the Annonaceae exhibit floral morphological characters which they partly share with other representatives of the order Magnoliales and further basal angiosperms, such as hermaphrodititic flowers, a usually trimerous perianth, and numerous stamens and carpels with a helical arrangement along an elongated, mostly convex receptacle. The three sepals are arranged in one whorl and the six petals are arranged in two whorls. Most Annonaceae are apocarpous and have sessile stigmas which usually become detached at the end of the pistillate phase. Besides these basic morphological floral characteristics there are other floral characters which can be interpreted as adaptations for pollination and the behavior and the senses of pollinators. Such functional characters apparently are protogyny, i.e., the functioning of the female reproductive organs before the male ones, the common curving of the petals towards the flower center during anthesis, thus providing a dark pollination chamber; further functional characters are thick petal tissues, many stamens which are tightly packed and shielded by a broadened apical prolongation of the connective, forming a roundish connective shield, and also profuse sticky stigmatic exudates, which protect, cover and connect the stigmas, functioning as a compitum; in the compitum, pollen tubes can cross between carpels which makes a regular distribution of pollen tubes possible (CARR and CARR, 1961, van HEUSDEN, 1992, ENDRESS,1994). Other important characters for pollination and functioning of Annonaceae flowers are the strong scent emissions and thermogenesis, flower warming, predominantly in species with nocturnal anthesis and pollination.

The aim of this study is to show how Annonaceae supposedly emerged as a beetlepollinated group, being visited by small fruit-beetles of the family Nitidulidae, which are attracted by an imitative fruit scent of flowers, and how other members of the family adapted to other insects. The prototype for the very early pollination mode in the family might be the genus Anaxagorea which apparently is the earliest divergent genus of the recent Annonaceae. Its species have diurnal, slightly thermogenic flowers with thick petals and a closed floral chamber where beetles of the genus Colopterus can hide during the pistillate phase and are released the second day of anthesis during the staminate phase. Another, very species-rich line of radiation in Annonaceae also has strong fruit-like floral scents but flowers do not warm up, such as in the genera Guatteria, Duguetia or small-flowered species of the genus Annona. A very special case is saprocantharophily in Duguetia cadaverica, in which the flowers by color and floral scent seem to imitate the fruiting bodies of stinkhorn fungi. Several species of Cymbopetalum, Annona, Duguetia and Malmea are pollinated by large dynastid scarab beetles; their flowers are large and tissue-rich and their nocturnally active flowers have accentuated thermogenesis and corresponding strong scent emissions.

Besides being most prominently pollinated by diurnally and nocturnally active, small- and large-bodied beetle groups, the Annonaceae during their evolutionary history have adapted also to thrips (Thysanoptera), e.g., in Bocageopsis or Popowia (MOMOSE et al., 1998), to cockroaches (one documented case in Uvaria elmeri; NAGAMITSU and INOUE, 1997), to flies (e.g. Pseuduvaria, Uvaria), and even bees (most spectacularly in Unonopsis species). Emphasis will be given to show the adaptational characters of the basically beetlepollinated Annonaceae flowers and to demonstrate which modifications and adaptations have occurred when other insects, especially thrips, flies and bees have entered as new pollinators. The Annonaceae as a very species-rich group are the only family of basal angiosperms for which the full capacity of evolutionary radiation of pollination modes can be traced (GOTTSBERGER, 2012).

\section{TOPICS DISCUSSED}

In this chapter examples are given for each of the main pollination modes occurring in the Annonaceae. Principally examples from the Neotropics are shown. The main morphological and functional floral characteristics are compared with the behavior of the flower visitors, considering floral rhythm, flower size and petal thickness, the structure of stamens and, as far as known, floral scent production.

\section{Pollination by small beetles}

\section{Anaxagorea}

The genus comprises 30 species (MAAS and WESTRA, 1984, 1985, CHATROU et al., 2012), with a disjunction distribution in the Neotropics and in tropical Asia. Reproductive biology and pollination of this early divergent genus was studied for six species in the Neotropics (TOL and MEIJDAM,1991, MAAS-VAN DE KAMER, 1993, WEBBER, 1996, ARMSTRONG and MARSH 1997, TEICHERT et al., 2011, BRAUN and GOTTSBERGER, 2011). 
A description of the flower morphology, anthesis and pollination biology of the widely distributed South American species A. dolichocarpa is given (BRAUN and GOTTSBERGER, 2011). The flowers have two whorls of cream-colored petals which are notably thick and fleshy. Flowers are protogynous with a long pistillate phase and a short pollen-dispersing staminate phase. Anthesis spanned two days. The petals opened just slightly by narrow slits in the early morning (Fig. 1a). Emission of a fruity, banana-like odor (consisting mainly of several fruit esters) started between 14:00 and 15:00 $\mathrm{h}$ and lasted in the early evening hours. The stigmas were covered with a gelatinous, translucent exudate. On the next morning the stigmatic exudates assumed a reddish color and slowly dried up. This ended the pistillate phase. The staminate phase began with the release of pollen at 10:00-11:00 h. Staminate phase flowers (Figure 1b) also had scent emissions, however somewhat earlier than the pistillate phase flowers in the population. The end of anthesis began between 14:45 and 15:45 $\mathrm{h}$ with the complete opening of the petals, a process that lasted 10 minutes. 2030 minutes after opening the petals fell off in quick succession. Flower temperatures were above ambient temperatures (value c. $3.5^{\circ} \mathrm{C}$ ) during the first hours of the pistillate phase and the later stage of the staminate phase until petal spreading. The pollinator attraction phase was during the scent emission period in the pistillate phase. Three morphospecies of small (1-3 $\mathrm{mm}$ ) beetles (Colopterus spp., Nitidulidae) were commonly and exclusively observed alighting on petals and entering the floral chamber, where they remained throughout anthesis. In the staminate phase the beetles commonly fed on pollen. Beetles leaving the flowers were regularly covered with pollen on all body parts.

Guatteria, Duguetia, and small-flowered Annona species

Guatteria is the largest genus of Annonaceae with 300 species (MAAS et al., in revision). The results of the few species investigated in the Atlantic and Amazon forests indicate that floral biology and pollination in Guatteria is conservative, being relatively similar in most species (GOTTSBERGER, 1970, WEBBER, 1996). Remarkable in Guatteria flowers is that their petals spread already in bud stage when the whole flower and its reproductive organs are still small and non-functional (Figure 1c). The green petals and all flower parts develop and increase in size for several weeks until attaining their final size, remaining during the whole period in this open bud stage. One day before anthesis the petals curve over the flower center forming with their base a closed, dark floral or pollination chamber (Figure 1c). During this process the petals become soft and change their color from green to yellow or brown. During the first day of anthesis the flowers start to emit a strong fruit-like, even fermenting smell, probably consisting of esters and alcohols. During this scented first day of flowering, the protogynous flowers attract beetles belonging to the Nitidulidae (Colopterus spp.) and Staphylinidae. During the night the stigmatic head (compitum) is shed, and in the early morning of the second day the flowers also shed their stamens and thus provide pollen. Stamens, pollen and beetles are kept for a short time in the still closed pollination chamber until the petals drop and the pollen-dusted beetles are released. Thus anthesis, including pistillate and staminate stages lasts about $24 \mathrm{~h}$.

A quite similar floral biology can be observed in the Atlantic forest species Duguetia lanceolata (SILBERBAUER-GOTTSBERGER et al., 2003), in the Amazon forest species D. stelechantha (WEBBER, 1996) (Figure 1d), and in the cerrado species D. furfuracea (GOTTSBERGER, 1970, 1993). All these species are day-active without any measurable floral warming, have a small pollination chamber, emit fruit-like floral scents, and attract small nitidulid and other beetles as pollinators. For Asian and African species with and without thermogenesis see, e.g., Deroin (1989), Rogstad (1994), Momose (2005), Ratnayake et al. (2006, 2007), Gottsberger et al. (2011).

Annona cherimola, the cherimoya, $A$. squamosa, the sugar apple, $A$. reticulata, the custard apple and several other small-flowered Annona species, with edible and very much appreciated fruits, are also pollinated by beetles. Very often, this fact is largely or completely misunderstood or neglected, which has negative consequences for crop production (see Westerkamp and GOTTSBERGER, 2000). Thus, in the U.S. Agriculture Handbook (MCGREGOR, 1976), the high costs of hand pollination of cherimoya in California are considered and the need for basic pollination studies in the homeland of this species is suggested. McGregor (1976), an apiculturist, even makes the curious suggestion to try "saturation pollination" with honeybees (Apis mellifera), based on the simple fact that this procedure "has proven feasible on some other crops". In his book, Free (1993) also misinterprets the pollination biology of the Annonaceae. In the FAO textbook Pollination of Cultivated Plants in the Tropics it is stated that "visitors and pollinators have seldom been observed but include beetles, especially the dynastine scarabs, 
Cyclocephala." (ROUBIK, 1995).

The accumulated knowledge on Annonaceae pollination, however, should be considered more adequately. Honeybees cannot be potential visitors because they are completely unable to enter the small pollination chamber of the protogynous Annonaceae flowers during receptivity of the stigmas (for the very rare bee pollination mode in Annonaceae by euglossine bees in the genus Unonopsis see below). It has long been known that small, flat nitidulid beetle species are the effective pollinators of these small-flowered Annonaceae to which they are attracted by fruity odors, and not dynastid scarabs like Cyclocephala (see WESTER, 1910, GOTTSBERGER, 1977, 1985, 1989, 1999, WEBBER 1981, 1996).

Sugar apple and cherimoya, even planted outside their natural range, are visited there also by nitidulid beetles, which are principally responsible for fruit set (for ISRAEL see GAZIT et al., 1982; for Florida see NADEL and PENA, 1994).

The pollinating nitidulid beetles of Annonaceae develop on rotting fruits (GOTTSBERGER, 1970. Teichert et al., 2011). Therefore, it would be relatively easy to augment their populations in plantations of Annona by simply offering breeding sites for the beetles. This would economize costs and make hand pollination unnecessary.

\section{$\underline{\text { Pollination by large beetles }}$}

\section{Large-flowered Annona species}

Several forest and cerrado species of the genus have large flowers (3-4 cm diam) with thick petals, such as Annona montana, A. glabra, A. paludosa, A. densicoma, A. coriacea, A. aurantiaca, A. warmingiana, A. monticola, A. crassiflora, A. dioica, A. tomentosa and $A$. cornifolia, and attract large (17-21 mm long) dynastid scarab beetles of the genus Cyclocephala (e.g. GOTTSBERGER, 1989). Some species finish their anthesis during one night (A. glabra, A. crassiflora); the majority of the species have a two-night flower rhythm with the pistillate stage during the first night and the staminate stage during the second night. A. cornifolia seem to have one-night, two-night and even three-night flowers (GOTTSBERGER, 1989).

Annona coriacea (Figure 1e and 1f) is an example of a cerrado species with a two-night rhythm (GOTTSBERGER, 1989). The pendulous flowers (4 cm diam.) never completely spread their imbricate internal petals; during the whole anthesis these petals cover the reproductive organs and provide a spacious pollination chamber for the beetles. It was found that the flowers heat up in the first night in the pistillate stage and also in the second night in the staminate stage. Maximum heating in both nights was $34{ }^{\circ} \mathrm{C}$, which was about $12-14{ }^{\circ} \mathrm{C}$ above ambient temperature. Concomitant with the thermogentic process large amounts of principally one scent compound, the nut-like 4-methyl-5vinylthiazole (98\%; MAIA et al., 2012) attracted the sole pollinator, Cyclocephala atricapilla. In the first evening, during the pistillate stage of the flowers, the beetles (females and males) began to arrive shortly before 20:00 h, which coincides with the initiation of the accentuated flower heating. When a flower was approaching its temperature peak the number of beetles arriving notably increased. After the thermogenic peak at 21:00 h, the flowers started to cool down and at about 22:00 $\mathrm{h}$ the approach of beetles ceased. The beetles landed at the external side of the petals and crawled between the imbricate inner petals into the pollination chamber, which can shelter up to 15 beetles. Once inside the pollination chamber the beetles gnaw nutritious tissue at the inner side of the internal petals, lick on the sticky stigmatic exudates and also mate. The warming of the flower and the scent volatilization during the staminate phase in the second night may attract another crowd of beetles. The beetles from the first and the second night become now covered with liberated, sticky pollen grain tetrads. Pollen is then the main food for the beetles. All beetles inside the pollination chamber are suddenly released from the flower by the dropping of the petals, which occurs about half an hour before other flowers in the first night pistillate stage attain their temperature and scent emitting maximum. A flight of the pollen-carrying beetles to the heated and scented, receptive, first-night flowers guarantees pollination. Also the flowers of this species, as occurs in many other Annonaceae, attract beetles and flies which use the flowers as brood substrate.

Also species of Cymbopetalum, Duguetia and Malmea (SCHATZ, 1990, WEBBER, 1996, BRAUN et al., 2011) in South and Central America, as well as species of Asimina in Florida (NORMAN and CLAYTON, 1986) and Uvariodendron in tropical Africa (GOTTSBERGER et al., 2011) are pollinated by large-bodied beetle species

\section{Saprocantharophily in Duguetia cadaverica}

This species, a small understory tree of humid primary forests from the Guianas to the state of Pará, Brazil, has several unusual characters such as flagelliflory and putrid smelling flowers (TEICHERT 
et al. 2012). The flagelliflorous inflorescences are very close to the ground and sometimes the flowers appear to be arising directly from the soil. The outer and inner petals are crimson-colored with the inner ones forming a white spongy central part (Figure 2a). Flowers are protogynous and last for about $24 \mathrm{~h}$. The flowers begin to at open a 05:00 $\mathrm{h}$ in the morning and at about the same time they start to emit scent, and stigmas are shiny with exudates while anthers are indehiscent (pistillate stage). Between 16:00 and 17:00 $\mathrm{h}$ stigmas become dry and scent is diminished. At that time anthers open and pollen is shed, indicating the beginning of the staminate stage. The following morning from 05:00 $\mathrm{h}$ onwards, the petals and stamens drop, marking the end of anthesis.

The unpleasant scent of $D$. cadaverica flowers is reminiscent of mature Camembert cheese, mushrooms and old damp socks with an additional vomit-like note. Chemically the scent is characterized by a combination of $\mathrm{C} 8$ fungal compounds, 4-methylpentanoic acid (e.g. occurring in Camembert cheese) and oligosulfides (being otherwise produced by carcass). This stench attracted a small nitidulid beetle (Pycnocnemus sp.) belonging to the tribe Cyllodini, which group is known as visitors of the fruiting bodies of stinkhorn fungi. Thus, the flowers of $D$. cadaverica are interpreted to be a Phallales fungus mimicry (TEICHERT et al. 2012). This is the first reported case of flowers mimicking fungi in Annonaceae, and saprocantharophily in Duguetia cadaverica might be perhaps the first well documented case of this novel pollination mode for the whole flowering plants.

\section{Pollination by thrips (Thysanoptera)}

Bocageopsis multiflora has a vast geographical distribution in the Brazilian Amazon and the Guianas. The flowers in inflorescences are small $(8-10 \mathrm{~mm}$ diam.) and the petals are greenish-cream during anthesis. Notable are the stamens, as they have a prolonged, triangular tongue-shaped connective. Anthesis starts very early in the morning. The internal petals only open partly and form a triradiate slit at the apex (Figure 2b). The receptivity of the stigma lasts for about 12 hours until late afternoon of the first day. The staminate stage begins at about 5:00 $\mathrm{h}$ in the morning of the second day and lasts about three hours, after which pollen is liberated and stamens are shed.

The sweetish-rancid floral odor during anthesis recalls that of the fruits of Genipa americana. The scent is weak during the early morning of the first day but intensifies during the day. It becomes weak during the night and intensifies again during the morning of the staminate stage. The only visitors of the flowers were thrips, which entered the pollination chamber via the triradiate slits of the inner petals. By dropping of the petals at the end of the staminate stage, the pollen-covered insects were forced to leave the flower and eventually flew to a scented pistillate or staminate flower (WEBBER and GOTTSBERGER, 1995).

\section{Pollination by flies}

Fly pollination is not well documented for Annonaceae in the New World tropics. It was suspected for one Annona species in the Peruvian Amazon region, which has petals with "light windows", a character of myiophilous flowers (SILBERBAUER-GOTTSBERGER et al., 2003). The Central American Sapranthus species because of the purple color of their flowers and the unpleasant scent were interpreted as being sapromyiophilous, but authors found beetles as flower visitors (SCHATZ, 1987, OLESEN, 1992), which would be a hint that they are perhaps saprocantharophilous. Further studies are needed to unequivocally demonstrate myiophily and sapromyiophily for Neotropical Annonaceae species.

On the other hand, fly pollination is well documented for Asian/Australian species of Pseuduvaria (SILBERBAUER-GOTTSBERGER et al., 2003) (Figure 2c). Species are dioecious, and pistillate and staminate flowers have nectar glands which attract small flies. Wine-red coloration at the adaxial side of the petals, as well as an unpleasant scent reminiscent of old dishwater and vomit of both the mitriform pistillate and staminate flowers are typical characteristics of a sapromyiophilous pollination mode. Also the flowers of the Central African species Monodora tenuifolia, Uvariopsis bakeriana (Figure 2d) and U. congolana (Figure 2e) have myiophilous/sapromyiophilous characteristics (GOTTSBERGER et al., 2011).

\section{Pollination by bees}

The small Neotropical genus Unonopsis (28 species) was recognized as being melittophilous in the nineties when studying $U$. guatterioides around Manaus (CARVALHO and WEBBER 2000, SILBERBAUER-GOTTSBERGER et al. 2003). The flowers emit a strong sweet scent similar to lemon grass and vanilla. Males of Eulaema bombiformis (Euglossini, Apidae) were observed to visit flowers in the pistillate and staminate stages and to pollinate 
them while collecting perfume.

A more detailed study was done on $U$. stipitata in French Guiana (TEICHERT et al., 2009). The flowers of U. stipitata, as was also observed in $U$. guatterioides, do not form a closed floral chamber, but remain open and accessible (Figure 2f). The flowers have a diurnal protogynous anthesis which lasts for 2 days. On the first day of anthesis, between 10:00 and 15:00 h, the flowers are in the pistillate stage and emit a spearmint-like odor. At 9:00 h on the second day, the spearmint-like odor production is resumed. From 11:00 h onwards the flowers change from the pistillate to the staminate stage, when anthers open and pollen is shed. Anthesis ends with the dropping of petals at 14:00 $\mathrm{h}$ on the second day.

The main flower visitors of $U$. stipitata were male bees of Euglossa imperialis (Figure 2f) and E. bombiformis. On the first day of anthesis bees visited the flowers at very irregular intervals and always only for a few seconds. On the second day of anthesis, the bees visited the flowers more frequently and remained at the flowers for longer periods. They brushed the osmophores on the inner side of the inner petals. During these movements, the bees had intense contact with the flower stigmas and anthers. While visiting transitional pistillate-staminate stage flowers, the bees were dusted with pollen on their heads and mouthparts. After a while, the bees flew up and hovered in front of a flower and transferred the collected fragrances from their front tarsi, over the midlegs, to the hind tibia.

The floral scent had 25 components, mainly monoterpenoids. Most of them were only found in low amounts. Only six compounds reached at least $5 \%$, i.e. alpha-pinene (12\%), limonene (27\%), trans-limonene oxide (9\%), 1,8-cineole $(7 \%)$ and trans-carvone oxide (19\%). Trans-carvone oxide is considered the scent that evolved convergently in euglossine-pollinated plants (WHITTEN et al., 1986). The fact that the basal Annonaceae also have members that have evolved such a sophisticated pollination syndrome where male euglossine bees collect perfume, a phenomenon that was first discovered in orchids and later in a few other groups, is most surprising. It is an indication that the Annonaceae were and maybe are still diversifying vigorously. 

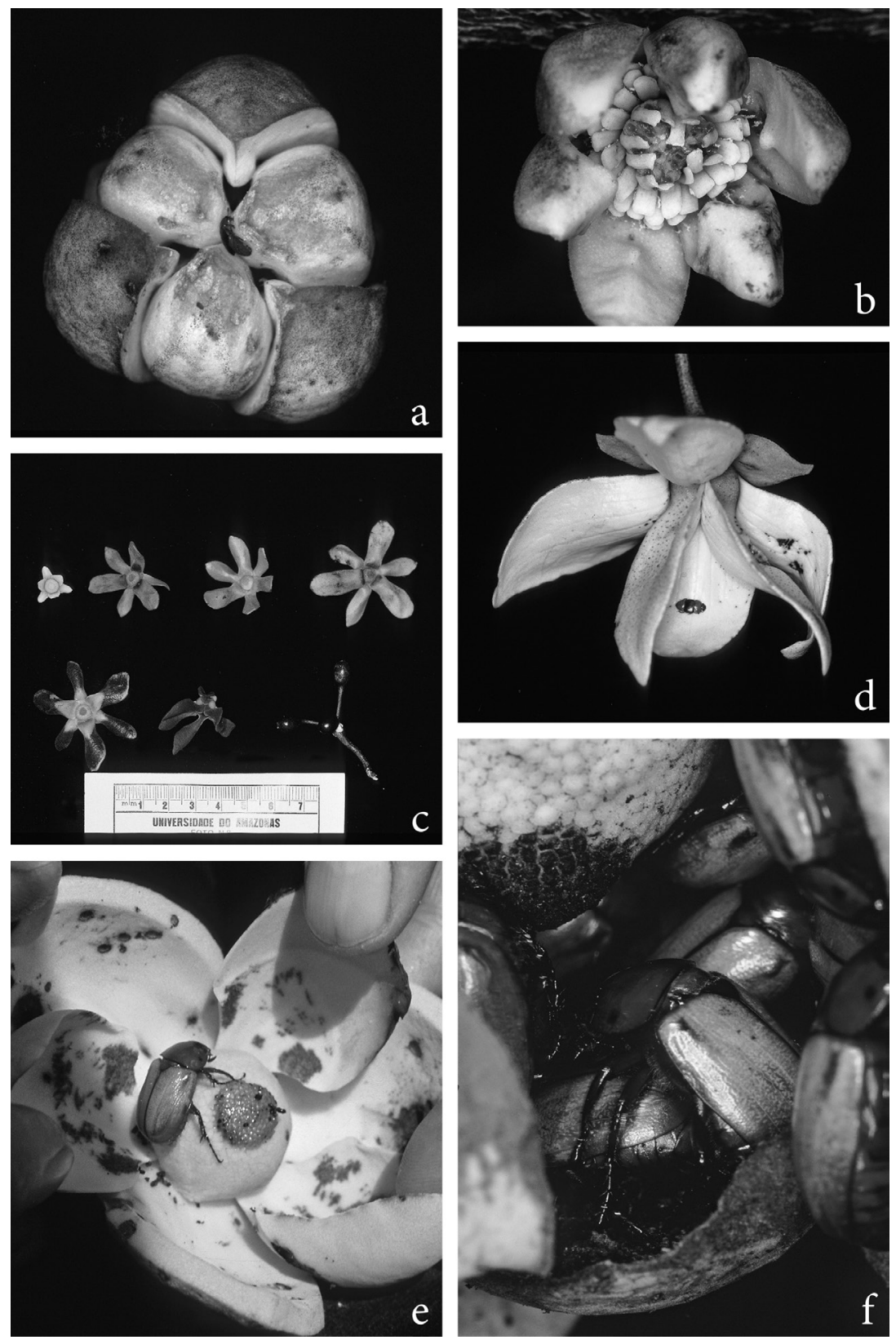

FIGURE 1- Flowers of Neotropical Annonaceae species. a, Anaxagorea brevipes. Flower (2 cm diam.) in pistillate stage with closed petals. One Colopterus sp. beetle crawling on petals before squeezing through the small openings and entering the pollination chamber. b, Anaxagorea dolichocarpa (outer petals $1.4 \mathrm{~cm}$ long). Flower in staminate stage with open petals. Staminodes curved towards dried stigmas. Stamens have open anthers and exposed pollen. c, Guatteria foliosa. Open green buds in different developmental stages (upper row), and two flowers (lower row), the left one with brown petal tips shortly before entering anthesis. The right flower is in anthesis and exhibits closed dark brown petals forming at their base a pollination chamber. At the right is one ripe tricarpellate fruit. Scale in centimeters. d, Duguetia stelechantha. Flower in anthesis (external petals $3.5 \mathrm{~cm}$ long). Internal petals form a closed floral chamber. One pollinating beetle (Colopterus sp.) crawling on petal before entering the floral chamber. e and f, Annona coriacea. e, a flower (petal length $5.5 \mathrm{~cm}$ ) in pistillate stage opened to show its interior with gnawing marks on inner side of petals, one pollinating beetle (Cyclocephala atricapilla) and the shining receptive stigmas. $\mathrm{f}$, several $C$. atricapilla individuals (one pair mating) inside the pollination chamber. Note dark, dried stigmas and still closed anthers, indicating that the flower is in the post-pistillate/pre-staminate stage. 

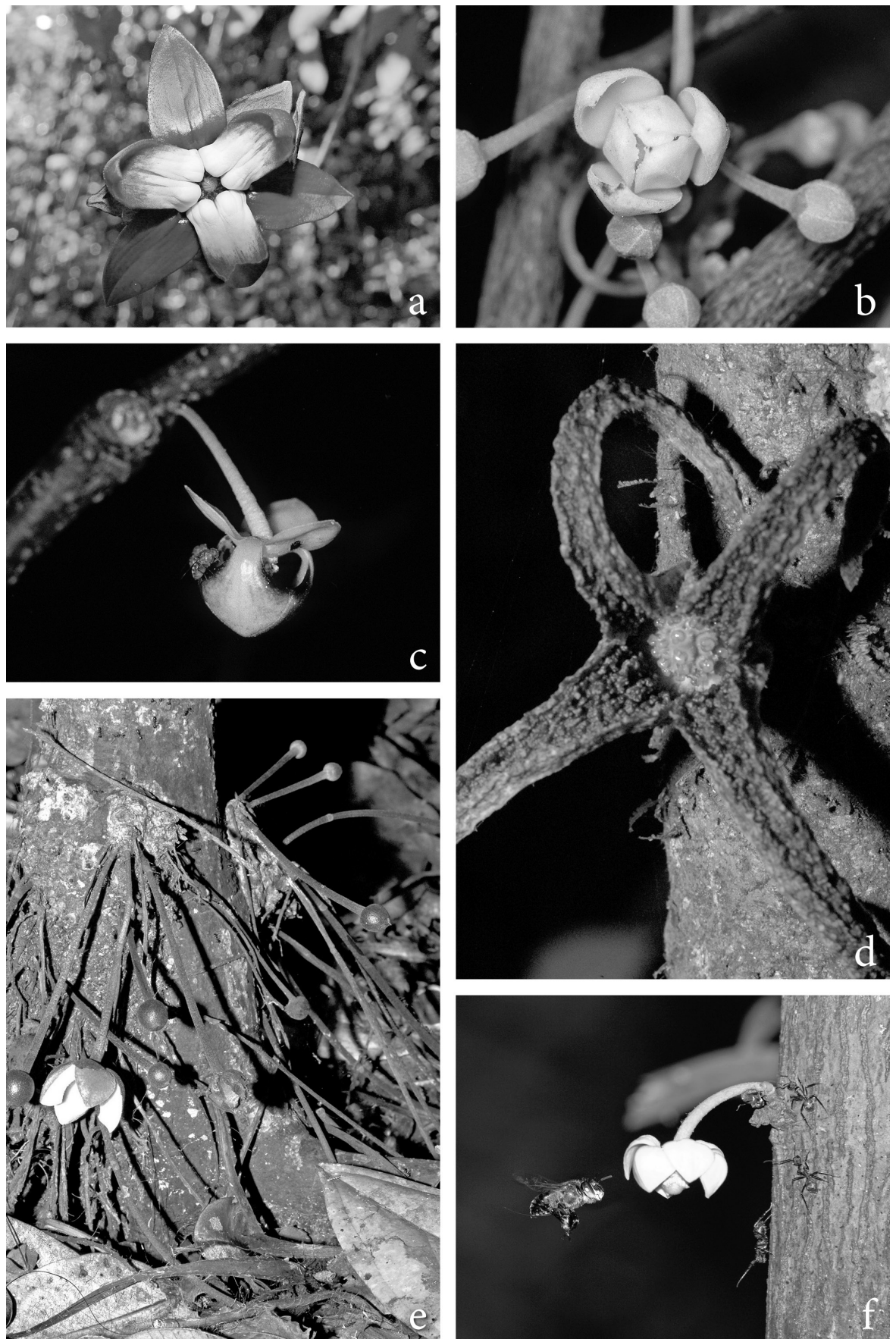

FIGURE 2- Flowers of Neotropical, Australian and African Annonaceae species. a, Duguetia cadaverica. Red flower (4 cm diam.) with white center surrounding the entrance of the pollination chamber. $\mathrm{c}$, Bocageopsis multiflora. Small greenish-cream flower (external petals $6 \mathrm{~mm}$ long) in pistillate stage with inner petals closed and exhibiting openings in form of narrow slits. c, Pseuduvaria hylandii. Small flower (1.3 cm diam.) with external petals spreading and exposing the dark purple interior of the inner petals. Two flies licking nectar. d, Uvariopsis bakeriana. Receptive female flower with red fleshy petals $(5.5 \mathrm{~cm}$ long) with tuberculate surface. e, Uvariopsis congolana. Flowers (open flower $2.5 \mathrm{~cm}$ diam) formed on long peduncles at the base of the trunk. f, Unonopsis stipitata. A male Euglossa imperialis approaching a flower (3 cm diam.) to collect perfume (photo credit Holger Teichert). 


\section{CONCLUSIONS}

The genus Anaxagorea has a basal position in Annonaceae. It has a two-day lasting, protogynous anthesis, with a strict separation of the pistillate and staminate stages. This is the predominant and general anthesis rhythm in beetle- and fly-pollinated angiosperms. Pollinators which often remain for a longer time inside a flower, such as beetles, are the best and the most efficient pollinators when they bring pollen load when entering a flower, and carry away a new load when leaving the flower. This is the floral rhythm also of nearly all Annonaceae, the cantharophilous ones, as well as those pollinated by flies, thrips and cockroaches. Only the melittophilous species are an exception. In the melittophilous Uvaria concava and in Unonopsis species this strict protogynous dichogamy without overlapping of the pistillate and staminate stages is suspended. Although their flowers are protogynous as well, there is a period during which there is overlapping of both phases. It is exactly this overlapping of the two phases which allows the actively flower-changing bees to be effective pollinators of these few melittophilous Annonaceae species.

Another step with modifications in the size of flowers, the thickness of petal tissue and the warming of flowers is from flowers pollinated by relatively small beetles (Nitidulidae, Staphylinidae, Curculionidae, Chrysomelidae, and also thrips (Thysanoptera)), with a body length up to $7 \mathrm{~mm}$, to such pollinated by large beetles (Dynastinae, Rutelinae, Cetoniidae, all Scarabaeidae), with a body length of 14-20 mm. Relatively few small-flowered Annonaceae have thermogenesis, while nearly all large-flowered groups exhibit strong warming. Concomitant with this increased size is the bearing of thick petals tissue. Thermogenesis in Annonaceae is produced by respiration of starch accumulated in petals and at the same time thick petals are a nutritious substrate for voracious beetles. As long as petal tissue and the structure of a flower is kept intact, beetles may not need to leave the interior of the large pollination chamber, but can stay until the end of anthesis. Such a pollination chamber is very typical for nearly all cantharophilous species, but would not work in myiophilous/sapromyiophilous and melittophilous species. Beetles are small, flat or strong enough to squeeze between overlapped or otherwise closed petals, while flies and bees need free access to the reproductive organs; as adaptation to pollination by flies and bees their respective flowers remain open during anthesis. A unique feature for Annonaceae is the production of nectar by large glands at the border of the inner petals in Pseuduvaria, which functions as reward for attracted flies.

In the early divergent genus Anaxagorea the connective of the stamens is prolonged and triangular or tongue-like. Such plesiomorphic structure is maintained or reappeared in genera such as Bocageopsis or Xylopia, which have adapted to pollination by thrips or staphylinid beetles, insects that are known to eat pollen without gnawing petal tissue. In most other Annonaceae, a hard flattened, connective disk covers the stamens. Such connective disk might be not only an adaptation for protecting the staminate organs against voracious pollinators but also against predators of floral tissue.

As far as we know the chemical composition of floral scents, there have been different lines of developments in Annonaceae. For example, in species of Anaxagorea, fruity odors consisting of esters and alcohols prevail (JÜRGENS et al., 2000, TEICHERT et al., 2011, BRAUN and GOTTSBERGER, 2011). The scent composition of dynastid scarab beetlepollinated species is not fruity but sharp or nut-like, for example in Annona coriacea, consisting mainly of the sulphur- and nitrogen-containing heterocyclic 4-methyl-5-vinylthiazole (MAIA et al., 2012). In the stinkhorn flower mimic Duguetia cadaverica there is mainly a combination of fatty acid derivatives (with cheese and fungi compounds) and S-bearing compounds, typical for carcass. On the other hand, the melittophilous Unonopsis stipitata attracts its male euglossine bees with aromatic fatty acid derivatives such as a-pinene, limonene or trans-carvone oxide (TEICHERT et al., 2009). For a full account of the present knowledge of scents in Annonaceae flowers see Goodrich (2012).

Annonaceae have developed several pollination syndromes, and show respective morphological, functional and scent-related adaptations. What is most surprising for such an early basal angiosperm group is that its various pollination modes appear all highly specialized, attracting a few related or even only one specific pollinator species. The question remains to be answered why Annonaceae with regard to their flower biology and pollination are all specialists. Eventually, the reason for these general specialization processes was the early adaptation of flowers for beetles, which had to be lured and deviated from other substrates in order to become faithful pollinators. 


\section{ACKNOWLEDGEMENTS}

Best thanks go to Ilse Gottsberger for helping during the preparation of the manuscript, to Graciela Hintze for preparing the figures, and to Holger Teichert for providing the photograph of Unonopsis stipitata.

\section{REFERENCES}

ARMSTRONG, J. E.; MARSH, D. Floral herbivory, floral phenology, visitation rate, and fruit set in Anaxagorea crassipetala (Annonaceae), a lowland rain forest tree of Costa Rica. Journal of the Torrey Botanical Society, Lawrence, v. 124, p. 228-235, 1997.

BRAUN, M.; DÖTTERL, S.; GOTTSBERGER, G. Absence of pollinators and apomictic fruit production in an Atlantic rainforest population of Cymbopetalum brasiliense (Annonaceae). Plant Systematics and Evolution, New York, v. 296, p. 265-273, 2011.

BRAUN, M.; GOTTSBERGER, G. Floral biology and breeding system of Anaxagorea dolichocarpa (Annonaceae), with observations on the interval between anthesis and fruit formation. Phyton, Horn, v. 51, p. 315-327, 2011.

CARR, S. G. M.; CARR, D. J. The functional significance of syncarpy. Phytomorphology, New Delhi, v. 11, p. 249-256, 1961.

CARVALHO, R.; WEBBER, A. C. Biologia floral de Unonopsis guatterioides (A. DC.) R. E. Fr., uma Annonaceae polinizada por Euglossini. Revista Brasileira de Botânica, São Paulo, v. 23, p. 419423, 2000.

CHATROU, L. W.; PIRIE, M. D.; ERKENS, R. H. J.; COUVREUR, T. L. P.; NEUBIG, K. M.; ABBOT, J. R.; MOLS, J. B.; MAAS, J. W.; SAUNDERS, R. M. K.; CHASE, M. W. A new subfamilial and tribal classification of the pantropical flowering plant family Annonaceae informed by molecular phylogenetics. Botanical Journal of the Linnean Society, London, v. 169, p. 5-40, 2012.

DEROIN, T. Quelques aspects de la biologie florale d'une Annonacee savanicole: Annona senegalensis Pers. Mémoirs Societe Biogéografique, Paris, v. 3, p. 42-53, 1989.
ENDRESS, P. K. Diversity and evolutionary biology of tropical flowers. Cambridge: Cambridge University Press, 1994.

FREE, J.B. Insect pollination of crops. $2^{\text {nd }}$ ed. London: Academic Press, 1993.

GAZIT, S.; GALON, I.; PODOLER, H. The role of nitidulid beetles in natural pollination of Annona in Israel. Journal of American Society of Horticultural Science, Alexandria, v. 107, p. 849$852,1982$.

GOODRICH, K. R. Floral scent in Annonaceae. Botanical Journal of the Linnean Society, London, v.169, p. 262-279, 2012.

GOTTSBERGER, G. Beetle pollination and flowering rhythm of Annona spp. (Annonaceae) in Brazil. Plant Systematics and Evolution, New York, v.167, p.165-187, 1989.

GOTTSBERGER, G. Beiträge zur Biologie von Annonaceen-Blüten. Österreichische Botanische Zeitschrift, Wien, v. 118, p. 237-279, 1970.

GOTTSBERGER, G. Flower biological differentiation in Neotropical Annonaceae. Annonaceae Newsletter, Utrecht, v. 9, p. 29-33, 1993.

GOTTSBERGER, G. How diverse are Annonaceae with regard to pollination? Botanical Journal of the Linnean Society, London, v. 169, p. 245-261, 2012.

GOTTSBERGER, G. Pollination and dispersal in the Annonaceae. Annonaceae Newsletter, Utrecht, v. 1, p. 6-7, 1985.

GOTTSBERGER, G. Pollination and evolution in neotropical Annonaceae. Plant Species Biology, Quebec, v. 14, p. 143-152, 1999.

GOTTSBERGER, G. Some aspects of beetle pollination in the evolution of flowering plants. In: KUBITZKI, K. (Ed.). Flowering plants. Plant Systematic and Evolution, New York, v.1, p. 211226, 1977. Suplemento.

GOTTSBERGER, G.; MEINKE, S,; POREMBSKI, S. First records of flower biology and pollination in African Annonaceae: Isolona, Piptostigma, Uvariodendron, Monodora and Uvariopsis. Flora, London, v. 206, p. 498-510, 2011. 
HEUSDEN, E. C. H. VAN. Flowers of Annonaceae: morphology, classification, and evolution. Blumea, Leiden, v.7, p. 1-218, 1992. Suplemento

JÜRGENS, A.; WEBBER, A. C.; GOTTSBERGER, G. Floral scent compounds of Amazonian Annonaceae species pollinated by small beetles and thrips. Phytochemistry, New York, v. 55, p. 551-558, 2000.

MAAS, P. J. M.; WESTRA, L. Y. T. Studies in Annonaceae II: A monograph of the genus Anaxagorea A. St. Hil. Botanische Jahrbuecher fuer Systematik, Berlin, v. 105, p. 73-134, 1984.

MAAS, P. J. M.; WESTRA, L. Y. T. Studies in Annonaceae. II: A monograph of the genus Anaxagorea A. St. Hil. Botanische Jahrbuecher fuer Systematik, Berlin, v. 105, p. 145-204, 1985.

MAAS-VAN DE KAMER, H. Floral biology of Anaxagorea dolichocarpa, and some notes on flower biology in Annonaceae. Annonaceae Newsletter, Utrecht, v. 9, p. 19-24, 1993.

MAIA, A. C. D.; DÖTTERL, S.; KAISER, R.; SILBERBAUER-GOTTSBERGER, I.; TEICHERT, H.; GIBERNAU, M.; NAVARRO, D. M. A. F.; SCHLINDWEIN, C.; GOTTSBERGER, G. The key role of 4-methyl-5-vinylthiazole in the attraction of scarab beetle pollinators: a unique olfactory floral signal shared by Annonaceae and Araceae. Journal of Chemical Ecology, New York, v. 38, p. 10721080, 2012.

MCGREGOR, S. E. Insect pollination of cultivated crop plants. Washington: United States. Dept. of Agriculture, 1976. (Agriculture Handbook, 496)

MOMOSE, K. Beetle pollination in tropical rain forests. In: ROUBIK, D. W., SAKAI, S., KARIM, A. A. H. (Eds.), Pollination ecology and the rain forest. New York: Springer, 2005. p.104-110.

MOMOSE, K.; NAGAMITSU, T.; INOUE, T. Thrips cross-pollination of Popowia pisocarpa (Annonaceae) in a lowland dipterocarp forest in Sarawak. Biotropica, Washington, v. 30, p. 444-448, 1998.

NADEL, H.; PENA, J. E. Identity, behavior and efficacy of nitidulid beetles (Coleoptera: Nitidulidae) pollinating commercial Annona species in Florida. Environmental Entomology, College Park, v. 23, p. 878-886, 1994.
NAGAMITSU, T.; INOUE, T. Cockroach pollination and breeding system of Uvaria elmeri (Annonaceae) in a lowland mixed-dipterocarp forest in Sarawak. American Journal of Botany, Columbus, v. 84, p 208-213, 1997.

NORMAN, E. M.; CLAYTON, D. Reproductive biology of two Florida pawpaws: Asimina obovata and A. pygmaea (Annonaceae). Bulletin of the Torrey Botanical Club, New York, v. 113, p. 1622, 1986.

OLESEN, J. M. Flower mining by moth larvae vs. pollination by beetles and bees in the cauliflorous Sapranthus palanga (Annonaceae) in Costa Rica. Flora, London, v. 187, p. 9-15, 1992.

RATNAYAKE, R. M. C. S.; GUNATILLEKE, I. A. U. N.; WIJESUNDARA, D. S. A.; SAUNDERS, R. M. K. Pollination ecology and breeding system of Xylopia championii (Annonaceae): curculionid bettle pollination, promoted by floral scents and elevated floral temperatures. International Journal of Plant Science, Amsterdam, v. 168, p. 1255-1268, 2007.

RATNAYAKE, R. M. C. S.; GUNATILLEKE, I. A. U. N.; WIJESUNDARA, D. S. A.; SAUNDERS, R. M. K. Reproductive biology of two sympatric species of Polyalthia (Annonaceae) in Sri Lanka. I. Pollination by curculionid beetles. International Journal of Plant Science, Amsterdam, v. 167, p. 483-493, 2006.

ROGSTAD, S. H. The biosystematics and evolution of the Polyalthia hypoleuca species complex (Annonaceae) of Malesia. III. Floral ontogeny and breeding systems. American Journal of Botany, Columbus, v. 81, p. 145-154, 1994.

ROUBIK, D.W. Pollination of cultivates plants in the tropics. FAO Agricultural Services Bulletin, Rome, v. 118, 1995.

SCHATZ, G. Systematic and ecological studies of Central American Annonaceae. 1987. Thesis (Ph.D.) - University of Wisconsin, Madison, 1987.

SCHATZ, G. E. Some aspects of pollination biology in Central American forests. In: BAWA, K. S.; HADLEY, M. (Ed.). Reproductive ecology of tropical plants. Paris: Unesco Parthenon Publication Group, 1990. p.69-84. 
S IL B ER B A U E R - GOT T S B ER GER, I .; GOTTSBERGER, G.; WEBBER, A.C. Morphological and functional flower characteristics of New and Old World Annonaceae with respect to their mode of pollination. Taxon, Utrecht, v. 52, p. 701-718, 2003.

TEICHERT H.; DÖTTERL, S.; FRAME, D.; KIREJTSHUK, A.; GOTTSBERGER, G. A novel pollination mode, saprocantharophily, in Duguetia cadaverica (Annonaceae): a stinkhorn (Phallales) flower mimic. Flora, London, v. 207, p. 522-529, 2012.

TEICHERT, H.; DÖTTERL, S.; GOTTSBERGER, G. Heterodichogamy and nitidulid beetle pollination in Anaxagorea prinoides, an early divergent Annonaceae. Plant Systematics and Evolution, New York, v. 291, p. 25-33, 2011.

TEICHERT, H.; DÖTTERL, S.; ZIMMA, B.; AYASSE, M.; GOTTSBERGER, G. Perfumecollecting male euglossine bees as pollinators of a basal angiosperm: the case of Unonopsis stipitata (Annonaceae). Plant Biology, Stuttgart, v. 11, p. 29-37, 2009.

TOL, I.A.V. ; MEIJDAM, N.A.J. Field research on pollination and seed dispersal of Annonaceae (soursop family). 1981. Thesis (Doctoral) University of Utrecht, Utrecht, 1981.
WEBBER, A. C. Biologia floral de algumas Annonaceae na região de Manaus, Amazonas. 1981. Dissertação (Mestrado) - Instituto Nacional de Pesquisa da Amazônia, Manaus, 1981.

WEBBER, A. C. Biologia floral, polinização e aspectos fenológicos de algumas Annonaceae na Amazônia Central. 1996. Tese (Doutor) - Instituto Nacional de Pesquisas da Amazônia, Fundação Universidade do Amazonas, Manaus, 1996.

WEBBER, A.C.; Gottsberger, G. Floral biology and pollination of Bocageopsis multiflora and Oxandra euneura in Central Amazonia, with remarks on the evolution of stamens in Annonaceae. Feddes Repertorium, Berlin, v. 106, p. 515-524, 1995.

WESTER, P. J. Pollination experiments with Anonas. Bulletin of the Torrey Botanical Club, New York, v. 37, p. 529-539, 1910.

WESTERKAMP, C.; GOTTSBERGER, G. Diversity pays in crop pollination. Crop Science, Madison, v. 40, p.1209-1222, 2000.

WHitTEN, W. M.; WILliAMS, N. H.; ARMBRUSTER, S. W.; BATTISTE, N. A.; STREKOWSKI, L.; LINDQUIST, N. Carvone oxide: an example of convergent evolution in euglossinepollinated plants. Systematic Botany, Kent, v. 11, p. 222-228, 1986. 